כ OPEN ACCESS

\title{
Komunikasi Keberagamaan tentang Makna Ucapan Salam Om Swastiastu Antar Umat Beragama
}

\author{
Zikri Fachrul Nurhadi ${ }^{1}$, Achmad Wildan Kurniawan, Abdul Rofi, lis Zilfah \\ Adnan
}

Universitas Garut, Indonesia

Email: zikri_fn@uniga.ac.id ${ }^{1}$

\begin{abstract}
This research is motivated by the phenomenon of the pros and cons of greeting Om Swastiastu among officials. The purpose of this study is to find and explain more deeply about the motives, experiences and meaning of Om Swastiastu's greetings for communication between religions. The research method used in this research is the phenomenology method. While the data collection techniques used are nonparticipant observation, in-depth interviews, literature study and documentation. The subjects of this study were government officials or apparatuses who said Om Swastiastu greeting, amounting to 7 people and taking informants using purposive sampling. The results showed that the future motives (in order motive) greetings from Om Swastiastu were self existence and tolerance and motives from the past (because motive) greetings from Om Swastiastu were due to internal encouragement, the spirit of nationality, a sense of nationalism and the principle of neutrality. While the experience of saying $\mathrm{Om}$ swastiastu greetings is divided into pleasant experiences (positive), that is feeling valued, getting new political relations, good treatment, sympathy and growing solidarity between people while the unpleasant experience (negative) is mandating unfavorable treatment, derision in the form of harsh words, criticism and stay away from and considered to have no stance. While the meaning of Om swastiastu's greetings is to pray for salvation in the Hindu version, a word of thanksgiving and a greeting.

KEYWORDS: Diversity Communication, Meanings, Greetings, Om Swastiastu, Phenomenology
\end{abstract}

\begin{abstract}
ABSTRAK
Penelitian ini dilatarbelakangi oleh fenomena pro-kontra pengucapan salam Om Swastiastu di kalangan para pejabat. Tujuan penelitian ini adalah untuk menemukan dan menjelaskan lebih dalam mengenai motif, pengalaman dan makna ucapan salam Om Swastiastu bagi komunikasi antar umat beragama. Metode penelitian yang digunakan dalam penelitian ini adalah metode fenomenologi. Sedangkan teknik pengumpulan data yang digunakan adalah pengamatan non partisipan, wawancara mendalam, studi kepustakaan dan dokumentasi. Adapun subjek dari penelitian ini adalah pejabat atau aparatur pemerintahan yang mengucapkan salam Om Swastiastu yang berjumlah 7 orang serta pengambilan informan dengan menggunakan purposif sampling. Hasil penelitian menunjukkan bahwa motif masa depan (in order motive) ucapan salam Om Swastiastu yaitu sebagai eksistensi diri serta toleransi dan motif masa lalu (because motive) ucapan salam Om Swastiastu yaitu karena dorongan internal, semangat kebangsaan, rasa nasionalisme dan prinsip netralitas. Sementara pengalaman mengucapkan salam Om swastiastu dibagi menjadi pengalaman menyenangkan (positif) yaitu merasa dihargai, mendapatkan relasi politik baru, perlakuan baik, simpati dan tumbuhnya solidaritas antar sesama sedangkan pengalaman tidak menyenangkan (negatif) yaitu mandapatkan perlakuan kurang baik, cemoohan berupa perkataan kasar, kritik dan di jauhi serta dianggap tidak memiliki pendirian. Sedangkan makna ucapan salam Om swastiastu adalah mendoakan keselamatan dalam versi agama Hindu, ucapan bersyukur dan salam penyambutan.
\end{abstract}




\section{Pendahuluan}

Salam bukan sekadar ungkapan kasih-sayang, tetapi memberikan juga alasan dan logika kasih-sayang yang diwujudkan dalam bentuk doa pengharapan agar selamat dari segala macam duka-derita. Seorang pemeluk agama tertentu yang mengucapkan salam kepada orang lain meskipun berbeda keyakinan diartikan sebagai suatu bentuk toleransi, meskipun tidak semua pihak menyepakati akan hal tersebut. Salah satu contohnya seseorang yang mengucapkan salam Om Swastiastu kepada pemeluk agama Hindu meskipun orang tersebut bukan pemeluk agama Hindu, salam Om Swastiastu diucapkan sebagai suatu bentuk saling menghargai dan untuk menjaga kerukunan antar umum beragama. Meski begitu, peristiwa seperti ini menimbulkan pro dan kontra karena dinilai menyalahi aqidah atau kepercayaan agama tertentu yang tidak seharusnya dilakukan (balipost.co.id,2015). Bagi pemeluk agama Hindu istilah apapun yang diawali dengan kata Om diartikan sebagai sesuatu yang sangat sakral, penganut agama hindu menginterpretasikan makna ucapan "Om" sebagai suatu bentuk seruan atau simbol untuk memanjatkan do'a, puja serta puji kepada Tuhan mereka. Ucapan "Om" tersebut kemudian dilanjutkan dengan mengucapkan kata "Swasti" yang mempunyai makna keselamatan atau kebahagian dan kesejahteraan dan dilanjutkan dengan kata 'astu' sebagai penutup yang memiliki arti semoga. Salam 'Om Swastiastu' menjadi salam khas agama hindu yang maknanya semoga tuhan memberikan keselamatan, kesejahteraan dan kebahagiaan (Yahya, 2017). Om swastiastu sebagai bentuk salam pembuka yang biasa diberikan oleh seseorang kepada orang lain ketika bertemu sebagai bentuk penghormatan kepada umat yang memiliki keyakinan sama ataupun umat beda agama. Ucapan salam Om Swastiastu diikuti dengan simbol yang khusus, yaitu kedua tangan dicakupkan bersamaan di depan dada dengan ujung jari yang mengarah keatas akan tetapi bila keadaan yang tidak memungkinkan sikap ini boleh tidak dilakukan atau diterapkan (Aisyah, 2013).

Pemeluk agama Hindu memaknai Salam Om Swastiastu sebagai salam pembukaan dan salam penutup perjumpaan dan percakapan, selain itu untuk menunjukkan eksistensi pemeluk agama Hindu yang juga memiliki salam awal dan akhir seperti halnya agama lain dan saat ini ucapan salam Om Swastiastu 
telah menjadi salam resmi dalam sidang-sidang Dewan Perwakilan (Pejabat) maupun pertemuan resmi lainnya (Aga, 2006). Seorang yang menerima ucapan salam om swastiastu seyogyanya memberikan ucapan yang sama yaitu "Om Swastiastu" dengan sikap yang sama juga, yaitu mencakupkan kedua tangan bersamaan di depan dada. Tindakan pejabat tinggi Indonesia dalam mengucapkan salam dalam berbagai versi agama itu sudah seringkali terdengar, bagi kaum Hindu, "Om Swastyastu" adalah ucapan ibadah dan didalam hukum syariat agama Islam tidak dibenarkan mengikuti dan mempercayai makna ibadah dari agama lainnya (Salam, 2017).

Berdasarkan pemaparan terkait dengan makna ucapan salam Om Swastiastu yang diucapkan oleh para pejabat khususnya pejabat di wilayah J awa Barat maka bahwa fenomena ucapan salam dalam berbagai agama terjadi di kalangan pejabat di wilayah Jawa, hal ini didukung oleh data yang diperoleh dari informan penelitian ini yang menjelaskan bahwa persentasi pejabat di wilayah Jawa Barat yang mengucapkan salam dalam berbagai versi agama terutama salam Om swastiastu kurang dari $20 \%$ dari total keseluruhan pejabat yang berada di Jawa Barat. Hal tersebut dikarenakan mayoritas penduduk di Jawa Barat merupakan pemeluk agama Islam dengan persentase $97 \%$ kemudian Kristen 1,81\%, Budha 0,58\%, Hindu 0,22\% dan Sunda wiwitan 0,005\% (wikipedia, 2018).

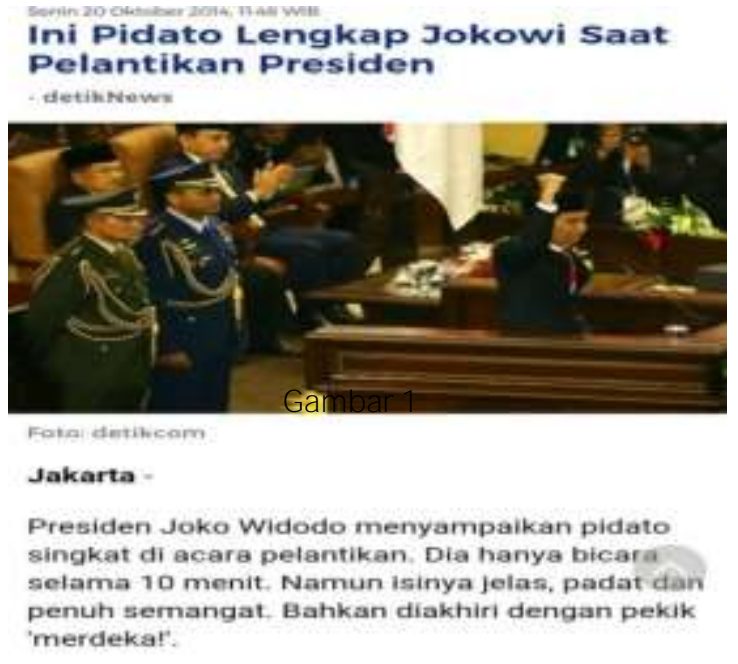

Presiden J oko Widodo menyampaikan pidato saat pelantikan Presiden RI Tahun 2014 
Kemudian yang terhangat adalah perdebatan mengenai ucapan salam dalam berbagai versi agama yang disampaikan oleh Presiden Joko Widodo dan Probowo Subianto yang di tahun politik ini mencalonkan menjadi calon presiden Republik Indonesia periode 2019-2024, peristiwa ucapan salam dalam berbagai versi agama terutama ucapan salam Om Swastiastu ini diucapkan oleh kedua tokoh politik.

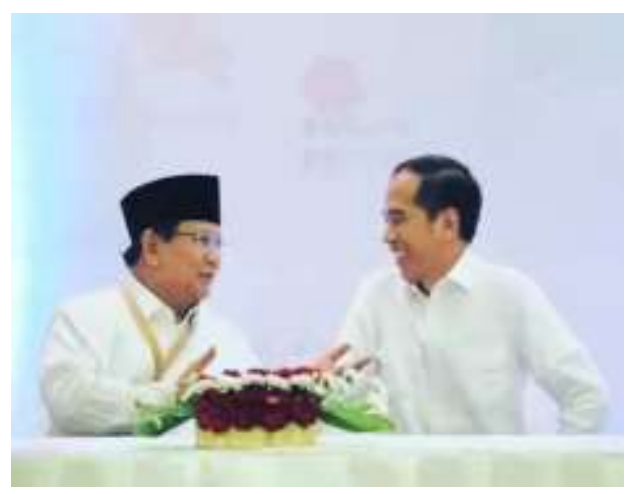

Gambar 2

J oko Widodo dan Probowo dalam acara pengambilan nomor urut capres dan cawapres RI periode 2019-2024

Setelah pengambilan nomor urut pasangan Capres dan Cawapres dipersilahkan menyampaikan pidatonya, Capres Ir. Joko Widodo memulai pidatonya dengan mengucapkan salam sebagai berikut: Bismillahirrohmani rrohiim, Assalamu 'alaikum, selamat malam, salam sejahtera bagi kita semuanya, Om Swastiastu, Namo Budhayya, salam kebaikan. Lalu setelah itu giliran H. Prabowo Subianto membuka pidatonya dengan ucapan salam sebagai berikut: Bismillahirrohmani rrohiim, Assalamu 'alaikum, salam sejahtera bagi kita sekalian, syalom, Om Swastiastu, namo budhaya, selamat malam saudara sekalian. Ungkapan salam Om Swastiastu merupakan suatu bentuk ibadah dalam agama Hindu oleh karenanya sangat terkait dengan konsep Tuhan dan sembahyang dalam agama Hindu, kata "Om" dalam agama Hindu berarti Tuhan dalam hal ini merujuk tuhan yang satu (Komarudin, 2015). Akan tetapi meskipun sama-sama menyatakan bertuahan satu agama-agama memiliki konsep Tuhan yang berbeda, dalam beberapa literatur agama Hindu terdapat penjelasan terkait konsep Tuhan dalam agama hindu yang intinya Tuhan dalam perspektif agama Hindu yakni Sang Hyang Widhi tidak bisa disamakan dengan Tuhan dalam 
perspektif Islam yakni Alloh SWT. Menurut Adian (2006:330) mengatakan untuk membangun toleransi bukan dengan mencampuradukan pemahaman tentang Tuhan, tetapi sebaliknya justru dengan mengakui perbedaan itu. Dalam pengertian ini, Khrisna bukan kristus, Sang Hyang Widhi bukan Alloh. Agama sebagai realitas sosial dalam kehidupan masyarakat pemeluknya telah dicirikan sebagai pemersatu aspirasi manusia yang paling tepat, karena Agama merupakan sumber inspirasi dan sumber tatanan masyarakat sebagai sesuatu yang menjadikan manusia mulia dan beradab (Hermawan, 2010).

Terkait dengan makna ucapan salam Om Swastiatu maka dikaji dengan menggunakan teori fenomenologi, Fenomenologi merupakan ilmu mengenai fenomena yang dibedakan dari sesuatu yang sudah menjadi, atau disiplin ilmu yang menjelaskan dan mengklasifikasikan fenomena, atau studi tentang Fenomena (Kuswarno,2013:1). Hal tersebut senada dengan penelitian terdahulu yang berjudul Pemahaman Hadist Larangan Mengucapkan dan Menjawab Salam Terhadap Non Muslim (Komarudin. 2015), penelitian terdahulu ini dilakukan mengkaji hadist tentang mengucapkan dan menjawab salam kepada NonMuslim, teori yang digunakan pada penelitian terdahulu ini adalah teori analisis yusuf qardawi dan menggunakan teknik penelitian pustaka (library research), penelitian terdahulu ini dikaji dengan menggunakan teori fenomenologi. Hasil penelitian terdahulu ini menunjukkan bahwa dalam proses komunikasi dengan konteks berbeda agama seorang muslim hanya diperbolehkan untuk menjawab atau membalas salam yang ditujukan kepada seorang Non-muslim, adapun mengucapkan salam dengan maksud menyapa Non-muslim tidak diperbolehkan secara akidah keislaman.

Adapun alasan peneliti memilih dewan legislatif yang berada di wilayah Jawa Barat khususnya di Garut sebagai objek penelitian, karena dengan keberagaman yang berada di Jawa Barat berupa keberagaman sosial, budaya terutama Agama, menjadi mayoritas di Provinsi Jawa Barat, sedangkan pemeluk agama Non-Islam yang berada di Provinsi Jawa Barat terutama agama Hindu merupakan pendatang yang berasal dari luar daerah dan keberagaman agama tersebut menjadi suatu hal yang sangat menarik untuk diangkat menjadi sebuah penelitian. Hal ini berdasar pada beberapa faktor yang telah dibahas sebelumnya, selain itu mengucapkan salam sudah dianggap lazim dilakukan bagi setiap 
pemeluk agama karena mengucapkan salam bagi sebagian orang merupakan suatu bentuk komunikasi yang telah menjadi kebiasaan dan dianggap tidak bertentangan dengan keyakinan meskipun mengucapkan salam kepada pemeluk agama yang berbeda. Fokus penelitian ini adalah bagaimana motif, pengalaman dan makna mengucapkan salam 'Om Swastiastu' sebagai komunikasi antar umat beragama ? Adapun tujuan penelitian ini adalah untuk menemukan dan menjelaskan Motif, pengalaman, makna ucapan salam 'Om Swastiastu' bagi komunikasi antar umat beragama.

\section{Metode Penelitian}

Metode penelitian yang digunakan pada penelitian ini adalah metode deskriptif dengan pendekatan kualitatif. Adapun gambaran informan pada penelitian ini adalah sebanyak 7 orang. Informan Peneliti adalah seseorang yang memiliki informan (data) banyak mengenai objek yang sedang diteliti dimintai informasi mengenai objek penelitian tersebut. Menurut Huberman dan Miles (dalam Bungin, 2010: 45) mengatakan bahwa informan juga berfungsi sebagai umpan balik terhadap data penelitian dalam ruang cross check data. Dalam penelitian fenomenologi ini peneliti menggunakan teknik purposive sampling. Menurut Creswell dalam (Kuswarno, 2013:57), bahwa penelitian fenomenologi melalui wawancara dengan informan yang jumlahnya berkisar antara 5-25 orang. Berikut daftar kriteria informan dalam penelitian ini adalah sebagai berikut : (1) Beragama Islam, (2) Memiliki intensitas tinggi dalam mengucapkan salam versi berbagai agama, (3) Berprofesi sebagai aparatur pemerintahan (Dewan Legislatif) atau aparatur negara (TNI/Polri), (4) Aktif dalam organisasi kemasyakatan atau Partai Politik.

Tabel 1 Daftar Informan

\begin{tabular}{cl|cll}
\hline No & \multicolumn{1}{c}{ Nama } & $\begin{array}{c}\text { Jenis } \\
\text { Kelamin }\end{array}$ & Usia & \multicolumn{1}{c}{ Profesi } \\
\hline 1 & H Majmudin Ma'ruf & Laki-laki & 52Th & Dewan Legislatif \\
2 & Ayi Nurlubis & Laki-laki & 47Th & Dewan Legislatif \\
3 & Briptu Aam Qusyaeri & Laki-laki & 28Th & Polisi \\
4 & Bripda Yusuf & Laki-laki & 27Th & TNI \\
5 & KH. Asep MA & Laki-laki & 59Th & Dewan Legislatif \\
6 & Suherman & Laki-laki & 47Th & Dewan legislatif \\
7 & M Fajar Trengginas IZ & Laki-laki & 28Th & Dewan legislatif \\
\hline
\end{tabular}


Sumber : Olah data peneliti

Teknik pengumpulan data pada penelitian ini adalah Wawancara mendalam dan obserpasi non partisipan. Adapun langkah-langkah peneliti dalam melakukan wawancara mendalam dengan informan yaitu :

1. Mencari informan sesuai dengan kriteria peneliti, kemudian melakukan komunikasi untuk perkenalan dan penjelasan kesediaan menjadi informan peneliti untuk selanjutnya akan diwawancarai.

2. Membuat penjad walan khusus dengan informan untuk melaksanakan wawancara mengenai makna ucapan salam Om Swastiastu.

3. Menjelaskan masalah yang ditanyakan tentang makna salam Om Swastiastu.

4. Melakukan wawancara untuk menggali informasi yang lengkap dan mendalam mengenai makna ucapan salam Om Swastiastu.

5. Peneliti menggunakan pedoman (guide) wawancara, karena jika menggunakan pedoman alur pertanyaan yang terlihat tidak bersifat baku tergantung kebutuhan lapangan.

Adapun langkah-langkah peneliti dalam melakukan observasi non partisipan pada penelitian tentang makna ucapan salam Om Sastiastu, adalah sebagai berikut :

1. Merumuskan bahan observasi yang akan dilakukan

2. Observasi dilakukan tanpa sepengetahuan informan

\section{Hasil Penelitian}

\section{Motif Informan mengucapkan salam Om Swastiastu}

Tindakan informan dalam mengucapkan salam Om Swastiastu merupakan tindakan yang tidak dibenarkan berdasarkan syari'at agama Islam, bahkan ucapan salam Om Swastiastu merupakan hal yang tabu di masyarakat umum. Adapun motif yang mendasari ucapan salam Om Swastiastu adalah sebagai berikut :

\section{Motif yang Berorientasi ke Masa Depan "untuk" (In Order Motive)}

\section{Eksistensi diri}

Motif tujuan mengucapkan salam Om Swastiastu sebagai bentuk eksistensi diri disampaikan oleh H. Majmudin Ma'ruf (informan 1), 
Berikut pemaparan yang disampaikan oleh H.Majmudin Ma'ruf terkait motif tujuan :

Tujuan saya menggunakan salam Om Swastiastu itu merupakan suatu bentuk eksistensi diri, melihat presiden dan menterimenteri mengucapkan salam berbagai agama salah satunya Om Swastiastu saya pun secara pribadi ingin memperlihatkan kualitas diri saya dan ikut mempopulerkan ucapan salam tersebut.

Hal yang sama disampaikan oleh M. Fajar Trengganis (Informan 7) yang menjelaskan bahwa Motif tujuan mengucapkan salam Om Swastiastu sebagai bentuk eksistensi diri. Berikut pemaparan yang disampaikan oleh M. Fajar :

Tujuan saya mengucapkan salam Om Swastiastu untuk menunjukan eksistensi diri, sebagai dewan legislatif muda saya harus bisa mengikutiapa yang sedang hangat di perbincangkan publik hal tersebut untuk memperkuat strategi politik saya dalam merangkul kaum muda atau milineal.

\section{Toleransi}

Motif tujuan mengucapkan salam Om Swastiastu sebagai bentuk toleransi disampaikan oleh Ayi Nurlubis (informan 2), menurut Ayi ucapan salam Om Swastiastu ini adalah salam kebangsaan yang diperkenalkan oleh Presiden dan kalangan Mentri dan mulai dicontoh oleh Dewan-dewan legislatif di berbagai daerah termasuk di Kabupaten Garut dan tujuannya adalah sebagai bentuk saling menghargai antar umat beragama. Berikut pemaparan mengenai motif tujuan yang disampaikan oleh Ayi Nurlubis:

Jelas bahwa tujuan saya mengucapan salam Om Swastiastu yang digunakan oleh dewan-dewan legislatif di berbagai daerah adalah wujud daritoleransi,toleransi disini sebagai suatu upaya yang dilakukan pemerintah dalam rangka mewujudkan sikap saling menghargai antar umat beragama. terlepas dari adanya pro kontra dari fenomena ini tetapi inilah salam kebhinekaan disinilah indahnya berdemokrasi.

Sama halnya dengan yang disampaikan oleh Suherman (Informan 6) yang memaparkan motif "untuk" mengucapksan salam Om Swastiastu yaitu bentuk toleransi. Berikut pemaparan dari Suherman : 
Tujuan saya mengucapkan salam Om Swastiastu yaitu untuk menunjukan sikap toleransi antar umat berbeda agama, terutama dengan keberagaman yang dimiliki oleh Kota Cirebon mengharuskan dewan pemerintahan untuk bisa menjaga rasa saling menghargai antar sesama.

Sementara itu KH. Asep MA (Informan 5) memberikan pemaparan mengenai motif "untuk" atau tujuan mengucapkan salam Om Swastiastu yaitu bentuk toleransi. Berikut pemaparan yang disampaikan oleh KH. Asep MA:

Insya Alloh Tujuan saya pribadi dalam mengucapkan salam om swastiastu yaitu bentuk toleransi, sebagai orang yang duduk di kursi dewan perwakilan rakyat senantiasa saya harus bersikap bijaksana dalam melakukan tindakan dan harus bisa memberikan tauladan yang baik kepada masyarakat terutama dalam hal sikap saling menghormati kepada non muslim.

\section{Motif yang Berorientasi ke Masa Lalu "karena"(Because Motive)}

Motif yang berorientasi kepada masa lalu atau "karena" (because motive) artinya sesuatu merujuk pada pengalaman masa lalu individu, karena itu berorientasi pada masa lalu. Dikutif dari paparan beberapa informan dapat diketahui bahwa motif ini dipengaruhi latar belakang dalam mengucapkan salam Om Swastiastu, adapun yang menjadi latar belakang ucapan salam dalam berbagai versi agama termasuk Om Swastiastu, yaitu:

\section{Faktor Dorongan Internal}

Faktor internal menjadi motif latar belakang ucapan salam Om Swastiastu yang di sampaikan oleh H. Majmudin Ma'ruf (Informan 1) yang menjelaskan bahwa latar belakang mengucapakan salam Om Swastiastu yaitu karena faktor atau dorongan internal dalam hal ini dorongan yang berasal dari internal praksi partai. Berikut penjelasan mengenai motif latar belakang yang disampaikan H Majmudin Ma'ruf: Sama halnya dengan yang disampaikan oleh Suherman (Informan 6) yang memaparkan mengenai motif "karena" atau latar belakang mengucapkan salam Om Swastiastu yaitu karena faktor internal. Berikut pemaparan dari Suherman : 
faktor internal saya sebagai dewan legislatif yang berasal dari partai nasional harus bisa bersikap toleran terhadap perbedaan, salam Om Swastiastu itu esensinya menghormati dalam bingkai kebhinekaan.

\section{Semangat kebangsaan}

Motif latar belakang semangat kebangsaan mengucapkan salam Om Swastiastu disampaikan oleh Ayi Nurlubis (Informan 2) yang menjelaskan bahwa yang menjadi latar belakang beliau mengucapkan salam Om Swastiastu adalah semangat kebangsaan yang timbul dari dalam diri sendiri. Berikut penjelasan yang di sampaikan Ayi Nurlubis memngenai latar belakang atau faktor mengucapkan salam Om Swastiastu:

Yang melatar belakangi saya untuk mengucapkan salam Om Swastiastu adalah semangat kebangsaan yang timbul dari dalam hati saya,berangkat dari kesadaran saya ini meskipun saya mengetahui bahwa tidak semua dewan khususnya di Kabupaten Garut yang menyukai salam berbagai versi agama.

Berdasarkan penjelasan yang disampaikan oleh Ayi terkait motif latar belakang atau faktor mengucapakan salam Om Swastiastu, beliau menjelaskan bahwa yang melatarbelakangi beliau mengucapkan salam Om Swastiastu adalah semangat kebangsaan, semangat kebangsaan tersebut berasal dari diri sendiri yang tumbuh sebagai warga negara yang ingin berperan dalam rangka menjaga kesatuan dan persatuan bangsa dengan menjaga sikap toleransi antar umat beragama. Senada dengan Ayi Nurlubis, Briptu Imam Qusyaeri (Informan 3) menjelaskan mengenai motif latar belakang atau faktor mengucapkan salam Om Swastiastu yaitu atas dasar semangat kebangsaan Berikut penjelasan yang disampaikan oleh Briptu Imam Qusyaeri terkait motif latar belakang atau faktor mengucapkan salam Om Swastiastu:

Latar bekalang saya mengucapkan salam dalam berbagai versi agama yaitu berangkat dari semangat kebangsaan yang saya miliki,sebagai seorang anggota kepolisian semangat kebangsaan selalu saya tanamkan dalam menjalankan tugas dan kewajiban saya sebagai anggota kepolisian. Terutama dalam hal menjaga keamanan dan kenyamanan serta kerukunan antar umat berbeda agama. 


\section{Sikap Nasionalisme}

Motif latar belakang sikap nasionalisme mengucapkan salam Om Swastiastu disampaikan oleh Ayi Nurlubis (Informan 2) yang menjelaskan bahwa yang menjadi latar belakang beliau mengucapkan salam Om Swastiastu yaitu karena sikap nasionalisme. Berikut penjelasan yang di sampaikan Ayi Nurlubis mengenai latar belakang atau faktor mengucapkan salam Om Swastiastu:

Selain karena semangat kebangsaan, yang menjadi latar belakang saya mengucapkan salam Om Swastiastu yaitu karena sikap nasionalisme, tindakan saya ini adalah wujud dari sikap nasionalisme yang saya miliki sebagai wakil dari suara rakyat saya harus bisa menjadi seorang profesisonal yang berperan dalam rangka menjaga kerukunan antar sesama pemeluk agama.

Berdasarkan pernyataan yang disampaikan oleh Ayi terkait latar belakang atau faktor mengucapkan salam Om Swastiastu yaitu karena sikap nasionalisme, beliau menjelaskan bahwa tindakannya dalam mengucapkan salam dalam berbagai versi agama termasuk ucapan salam Om Swastiastu yaitu sebagai wujud dari sikap nasionalisme yang beliau miliki. Menurut Ayi sebagai seorang dewan yang merupakan perwakilan dari suara rakyat harus menunjukkan sikap nasionalime dalam rangka menjaga kerukunan antar umat berbeda agama. Senada dengan yang disampaikan oleh Ayi, Briptu Imam Qusyaeri (Informan 3) juga menyampaikan bahwa latar belakang atau faktor mengucapkan salam Om Swastiastu yaitu sikap nasionalisme. Berikut pemaparan yang disampaikan Imam terkait motif latar belakang:

Latar belakang lainnya dalam mengucapkan salam Om Swastiastu yaitu karena sikap nasionalime sebagai aparat keamanan yang bertugas menegakan hukum di negara ini dan dituntut untuk bisa mengayomi masyarakat sikap nasionalisme ini menjadi landasan utama karena tanpa dilandasai dengan sikap nasionalisme tidak akan tercipta profesionalisme.

Berdasarkan penjelasan yang disampaikan oleh Imam sikap nasionalisme juga menajdi latar belakang mengucapksan salam Om Swastiastu, sebagai aparat keamanan yang bertugas menegakan hukum 
di negara ini serta mengayomi segenap lapisan masyarakat tentunya sangat di tuntut untuk bisa menunjukkan sikap profesional dan sikap profesional tersebut bisa diciptakan atas landasan nasionalisme yang berasal dari diri sendiri.

\section{Prinsip Netralitas}

Motif latar belakang prinsip netralitas mengucapkan salam Om Swastiastu disampaikan oleh Bripda Yusuf (Informan 4) yang menjelaskan bahwa yang menjadi latar belakang beliau mengucapkan salam Om Swastiastu yaitu karena sikap nasionalisme. Berikut penjelasan yang di sampaikan Ayi Nurlubis mengenai latar belakang atau faktor mengucapkan salam Om Swastiastu:

latar belakang atau faktor lainnya yang lebih spesifik lagi yang yakni karena prinsip netralitas yang selalu dijaga oleh seorang prajurit. Dalam aktivitas sehari-hari prajurit khususnya saya pribadi sangat memegang sikap netral, dan hubungannya dengan komunikasi dalam konteks agama prinsip netral ini maksudnya menghindari sangkaan keberpihakan pada sisi agama.

Berdasarkan penjelasan yang disampaikan oleh Bripda Yusuf (Informan 4) terkait motif latar belakang atau faktor mengucapkan salam Om Swastiastu yaitu prinsip netralitas, menurut beliau ucapan salam berbagai versi agama terutama ucapan salam Om Swastiastu bukan hanya suatu bentuk toleransi akan tetapi lebih dari pada itu ucapan salam ini merupakan wujud dari prinsip netralitas yang selalu dijaga oleh prajurit TNI. Bripda Yusuf menjelaskan bahwa bagi seorang prajurit prinsip netral menjadi prioritas, bersikap netral dalam segala aspek terutama kebebasan untuk memiliki keyakinan menunjukkan bahwa tidak ada keberpihakan dalam sisi agama.

\section{Salam Kebhinekaan}

Motif latar belakang salam kebhinekaan dalam mengucapkan salam Om Swastiastu disampaikan Ayi Nurlubis (Informan 2) yang menjelaskan terkait motif latar belakang atau "karena" mengucapkan 
salam Om Swastiastu, beliau menjelasakan bahwa latar belakang mengucapkan salam Om Swastiastu yaitu karena salam Om Swastiastu merupakan salam kebhinekaan. Berikut penjelasan yang disampaikan oleh Ayi Nurlubis mengenai motif latar belakang mengucapkan salam Om Swastiastu:

Alasan saya mengucapkan salam Om Swastiastu karena meskipun ucapan salam Om Swastiastu identik dengan agama Hindu akan tetapi salam ini merupakan salam kebhinekaan faktanya salam ini diucapkan oleh pejabat-pejabat pada level tertinggi di Indonesia. saya berpikir perbedaan itu nomor sekian ya kebersamaan dan persatuan dalam bhineka tunggal ika yang perlu diutamakan.

\section{Salam Pemersatu}

Motif latar belakang salam pemersatu dalam mengucapkan salam Om Swastiastu disampaikan oleh KH. Asep MA (Informan 5) yang menjelaskan bahwa latar belakang mengucapkan salam Om Swastiastu karean salam tersebut merupakan salam pemersatu. Berikut pemaparan dari KH. Asep MA:

Sebelumnya kita harus bersikap tabayun terhadap pejabat yang mengucapkan salam dalam berbagai versi agama termasuk ucapan salam Om Swastiastu, hal tersebut perlu dilakukan untuk mengetahui tujuan sebenarnya dari pejabat yang mengucapkan salam tersebut. kemudian yang melatar belakangi pejabat mengucapkan salam ini khususnya saya pribadi yaitu karena salam dari berbagai versi agama ini adalah salam pemersatu.

Berdasarkan hasil penelitian, maka dapat digambarkan dalam bentuk model motif mengucapkan salam om swastiastu, yaitu: 


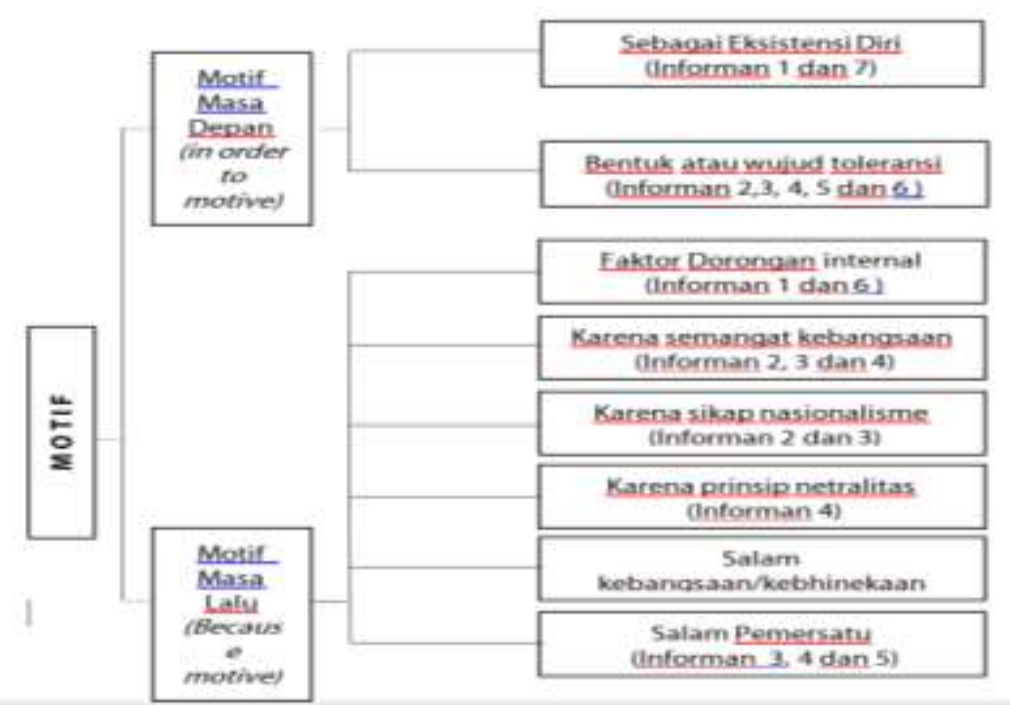

Bagan 1

Model Motif Mengucapkan salam Om Swastiastu

Sumber:Model kategorisasi hasil wawancara informan

\section{Pengalaman mengucapan salam Om Swastiastu}

Adapun pengalaman mengucapkan salam dalam berbagai versi agama termasuk salam Om Swastiastu dibedakan menjadi pengalaman menyenangkan (positif) dan pengalaman tidak menyenangkan (negatif).

\section{Pengalaman Positif}

Pengalaman postif yaitu peristiwa yang menyenangkan (positif) yang dialami oleh seseorang, berdasarkan hasil penelitian terdapat beberapa pengalaman menyenangkan (positif) yang dialami oleh informan yaitu sebagai berikut:

\section{Merasa lebih dihargai}

Pengalaman positif mengucapkan salam Om Swastiastu yaitu merasa lebih dihargai disampaikan oleh H. Majmudin (informan 1) beliau memaparkan pengalamannya sebagai berikut:

Pertama kali saya mengucapkan salam Om swastiastu ketika melakukan kunjungan kerja ke luar daerah dan kebetulan dalam kunjungan kerja tersebut ada beberapa dewan yang beragama Hindu, setelah itu setiap kali melakukan kunjungan kerja baik ke luar daerah ataupun dewan praksi dari luar daerah yang berkunjung saya tentu mengucapkan salam Om Swastiastu. 
Pengalaman positifnya dalam mengucapkan salam berbagai versi terutama ucapan salam Om Swastiastu yaitu secara pribadi merasa lebih di hargai oleh dewan legislatif lain meskipun mereka berbeda keyakinan dengan saya.

Senada dengan H. Majmudin, Ayi Nurlubis (Informan 2) memaparkan pengalaman positif mengucapkan salam Om Swastuastu yaitu merasa lebih dihargai. Berikut pemaparan pengalaman positif mengucapkan salam Om Swastiastu berdasarkan hasil wawancara dengan Ayi Nurlubis:

Karena fenomena ucapan salam ini terdapat pro konra di dalamnya oleh karenanya saya sebagai dewan yang mengucapkan salam dalam berbagai agama mengalami pengalaman positif dan negatif. Pengalaman positif nya yang saya rasakan setelah saya ikut mempolpulerkan ucapan salam Om Swastiastu yaitu saya merasa lebih dihargai oleh beberapa dewan yang berbeda agama dengan saya.

Sementara itu Briptu Imam Qusyaery (Informan 3) menyampaikan pengalaman positif mengucapkan salam dalam berbagai versi agama termasuk ucapan salam Om Swastiastu. Berikut pemaparan yang disampaikan oleh Briptu Imam Qusyaeri:

Untuk pengalaman positif mengucapkan salam Om Swastiastu yaitu saya merasa mendapatkan perhatian lebih dan lebih dihargai juga oleh teman-teman kepolisian yang berbeda agama dengan saya teruatama pemeluk agama Hindu.

\section{Mendapatkan relasi politik}

Pengalaman positif mengucapkan salam Om Swastiastu yaitu merasa lebih dihargai disampaikan oleh H. Majmudin (informan 1) beliau memaparkan pengalamannya sebagai berikut:

Selain dari lebih di hargai oleh dewan yang berbeda agama, pengalaman positif lainnya yang saya rasakan dengan mengucapkan salam om swastiastu yaitu mendapatkan relasi politik.hal ini merupakan dampak yang sangat baik bagi saya karena untuk memperluas jaringan relasi itu tidak semudah membalikan kedua telapa tangan oleh karenanya hal ini menjadi pengalaman yang sangat menyenangkan dan berkesan bagi saya. 
pengalaman positifnya dalam mengucapkan salam Om Swastiastu yaitu menambah relasi politik. Berikut pemaparan yang disampaikan oleh $\mathrm{M}$ Fajar :

Pengalaman yang saya rasakan dengan mengucapkan salam dalam berbagai versi agama termasuk ucapan salam Om Swastiastu yaitu bertambahnya relasi politik, sebagai seorang legislator muda yang sedang mengembangkan sayap politiknya hal ini merupakan kesempatan baik untuk memperkuat strategi politik saya.

Berdasarkan pemaparan yang disampaikan oleh Ayi mengenai pengalaman menyenangkan (positif) mengucapkan salam Om swastiastu yaitu memperluas atau mendapatkan relasi politik baru, beliau menyampaikan bahwa pengalaman yang terjadi kepada beliau dengan mengucapkan salam Om swastiasu yaitu bertambahnya relasi politik. Beliau menambahkan bahwa hal tersebut merupakan suatu hal positif dan kesempatan baik bagi dirinya sebagai legislator muda untuk memperkuat strategi politknya.

\section{Mendapatkan simpati dan perlakuan baik}

Pengalaman positif mengucapkan salam Om Swastiastu yaitu mendapatkan simpati dan perlakuan baik disampaikan oleh KH. Asep MA (Informan 5) yang memberikan pemaparan sebagai berikut :

Pengalaman positifyang saya alami dan rasakan sebagai akibat dari mengucapkan salam Om Swastiasu salahsatunya mendapatkan simpati dan perlakuan baik dari anggota dewan lainnya, sebenarnya apapun yang terjadi pada diri kita pada dasarnya adalah buah dari apa yang kita kerjakan sebelumnya, salam om swastiastu ini adalh suatu bentuk menghargai perbedaan yang ada dan pihak yang bersangkutan pun menyadari akan hal ini yang kemudian membalas dengan hal baik pula.

Sama halnya dengan Ayi nurlubis (informan 2) beliau memaparkan pengalamannya sebagai berikut:

Dengan mengucapkan salam dalam berbagai versi agama termasuk ucapan salam Om Swastiastu pengalaman yang saya alami yaitu mendapatkan perlakuan baik dari dewan-dewan 
lainnya terutama dari dewan yang berbeda agama, selain itu saya juga mendapatkan simpati yang lebih setelah saya menjalin keakraban dengan dewan yang non muslim.

Begitupun dengan yang dialami oleh Briptu Imam Qusyaeri (informan 3) yang memaparkan bahwa pengalaman menyenangkan yang beliau rasakan ketika menggunakan salam Om Swastiastu yaitu mendapatkan simpati dari berbagai pihak. Berikut pemaparan yang disampaikan Imam terkait pengalaman positif mengucapkan salam Om Swastiastu:

Selain dari merasa lebih di hargai, pengalaman menyenangkan yang pernah saya alami setelah mengucapkan salam Om Swatiastu yaitu adanya simpati dari berbagai pihak terutama dari anggota kepolisian yang beragama Hindu, saya mendapatkan pelajaran berharga bahwa unutk dapat diargai oleh oramg apalagi tidak seaqidah dengan kita, kita cukup menghargai nya dengan mudah yaitu dengan mengucapkan salam om swastiastu ini misalnya.

Senada dengan Imam, Bripda Yusuf (Informan 4) juga memaparkan pengalaman menyenangkan (positif) yang beliau alam setelah mengucapkan salam Om Swastiastu yaitu mendapatkan simpati dan perlakuan baik dari beberapa pihak. Berikut pemaparan Yusuf terkait pengalaman positif mengucapkan salam Om Swastiastu:

Saya juga mengalami pengalaman menyenangkan selain dari dihargai oleh prajurit militer yang beragaa Hindu saya juga mendapatkan simpati dan perlakuan baik dari mereka, dan tentunya hal ini memperkuat sikap saling menghargai antar sesama prajurit militer karena unutk prajuri militer sikap saling menghormati merupakan hal yang sangat penting sekali.

\section{Peningkatan rasa solidaritas}

Pengalaman positif mengucapkan salam Om Swastiastu yaitu adanya peningkatan rasa solidaritas antar sesama disampaikan oleh Bripda Yusuf (informan 4) beliau memaparkan pengalamannya sebagai berikut:

Pengalaman mengesankan lainnya yang saya alami yaitu saya merasakan adanya peningkatan rasa solidaritas antar sesama prajurit militer, ucapan salam yang saya gunakan ini menjadikan hubungan saya dengan prajurit militer di batalyon ini menjadi lebih dekat dan saya pun merasa lebih solid dalam bekerja sama 
baik ketika latihan keahlian ataupun latihan militer di lapangan ataupun dalam hal saling membantu satu sama lain

Sama halnya dengan yang disampaikan oleh Suherman (Informan 6) yang memaparkan pengalaman positifnya sebagai berikut :

Pengalaman baik yang saya alami dari mengucapkan salam dalam berbagai versi agama termasuk ucapan salam Om Swastiastu yaitu adanya meningkatnya sikap saling perduli atau solidaritas, dengan sesama dewan ataupun dengan tokoh masyarakat yang berbeda keyakinan dengan saya.

\section{Pengalaman Negatif}

Pengalaman negatif yaitu peristiwa yang tidak menyenangkan (negatif) yang dialami oleh seseorang, berdasarkan hasil penelitian terdapat beberapa pengalaman tidak menyenangkan (negatif) yang dialami oleh informan yaitu sebagai berikut:

\section{Mendapat pandangan negatif}

Pengalaman tidak menyenangkan (negatif) mengucapkan salam Om Swastiastu yaitu mendapatkan pandangan negatif disampaikan oleh $\mathrm{KH}$. Asep MA (Informan 5) yang memberikan pemaparan sebagai berikut:

Negatif nya dari mengucapkan salam dalam berbagai versi agama termasuk ucapan salam Om swastiastu yakni timbulnya pandangan negatif khususnya kepada saya meskipun saya sudah memberikan penjelasan terkait ucapan salam tersebut, akan tetapi tetap saja pandangan negatif selalu ada dari beberapa pihak yang kurang berkenan atas tindakan saya.

Sama hal dengan yang disampaikan H. Majmudin (informan 1) beliau memaparkan pengalamannya sebagai berikut:

Pengalaman tidak menyenangkan yang saya alami setelah mengucapkan salam Om Swastiastu yaitu adanya pandangan negatif tentang saya, pihak yang tidak suka kepada saya mengatakan bahwa saya sebagai dewan yang dengan background partai islam dan tokoh agama tindakan saya mengucapkan salam dalam berbagai versi agama jelas tidak mencerminkan background saya tersebut, mereka yang tidak suka dengan saya memberian kritik dengan narasi yang menjatuhkan saya.

Senada dengan H. Majmudin, M Fajar (Informan 7) juga pernah mengalami pengalaman negatif akibat dari mengucapkan salam Om 
Swastiastu. Berikut pemaparan dari M Fajar:

Saya pernah mendapatkan pandangan negatif dari beberapa pihak yang mengatas namakan diri mereka sebagai ikatan pemuda Islam, mereka mengatakan bahwa tindakan saya itu salah dan bertentangn sekali dengan syariat agama. Kemudian saya juga mendapatkan kritik berupa perkataan yang tidak sopan kepada saya.

\section{Mendapat cemoohan}

Pengalaman tidak menyenangkan (negatif) mengucapkan salam Om Swastiastu yaitu mendapatkan cemoohan disampaikan oleh Ayi Nurlubis (informan 2) beliau memaparkan pengalamannya sebagai berikut:

Pengalaman tidak menyenangkan yang saya alami setelah mengucapkan salam dalam berbagai versi agama termasuk ucapan salam Om Swastiastu yaitu mendapatkan cemoohan dari beberapa oknum sampai dengan mendapatkan reaksi berlebihan beruapa cemoohan dengan bahasa kasar akan tetapi saya tidak menanggapinya terlalu serius menurut saya itu hanya reaksi dari ketidak pahaman masyarakat.

\section{Mendapat kritik sampai di jauhi}

Pengalaman tidak menyenangkan (negatif) mengucapkan salam Om Swastiastu yaitu mendapatkan kritik sampai di jauhi disampaikan oleh Briptu Imam Qusyaeri (informan 3) beliau memaparkan pengalamannya sebagai berikut:

Adapun pengalaman tidak menyenangkan yang saya alami setelah mengucapkan salam dalam berbagai versi agama termasuk salam Om Swastiastu yaitu mendapatkan kritik sampai dijauhi oleh orang yang bersangkutan, pengalaman ini saya dapatkan ketika menyampaikan sambutan pada suatu kegiatan masyarakat dan saya mengucapkan salam om swastiastu karena setahu saya terdapat keluarga yang beragama Hindu di komplek perumahan tersebut.

Sama halnya dengan Suherman (Informan 6) yang memaparkan pengalaman tidak menyenangkan (negatif) mengucapkan salam Om Swastiastu yaitu mendapatkan kritik sampai di jauhi. Berikut pemaparan yang disampaikan oleh Suherman:

Pengalaman negatif yang pernah saya alami bahkan sampai sekarang pun masih sering terjadi karena kebiasaan saya mengucapkan salam dalam berbagai versi agama yakni 
salahsatunya saya di jauhi oleh sebagai orang. Akan tetapi menurut saya bukan karena tindakan saya ini orang-orang tersebut menjauhi saya memang karena dari awalnya tidak suka kepada saya.

\section{Dianggap tidak punya pendirian}

Pengalaman tidak menyenangkan (negatif) mengucapkan salam Om Swastiastu yaitu dianggap tidak punya pendirian disampaikan oleh Bripda yusuf (informan 4) beliau memaparkan pengalamannya sebagai berikut:

Untuk pengalaman negatif yang pernah saya alami yaitu saya pernah mendapatkan kritik karena menggunkan salam dalam berbagai versi agama termasuk salam Om Swastiastu sampai dianggap tidak punya pendirian, padahal yang saya lakukan itu untuk menghargai sesama prajurit militer tidak peduli apapun agamanya akan tetapi beberapa pihak yang tidak sependapat memiliki pandangan yang berbeda.

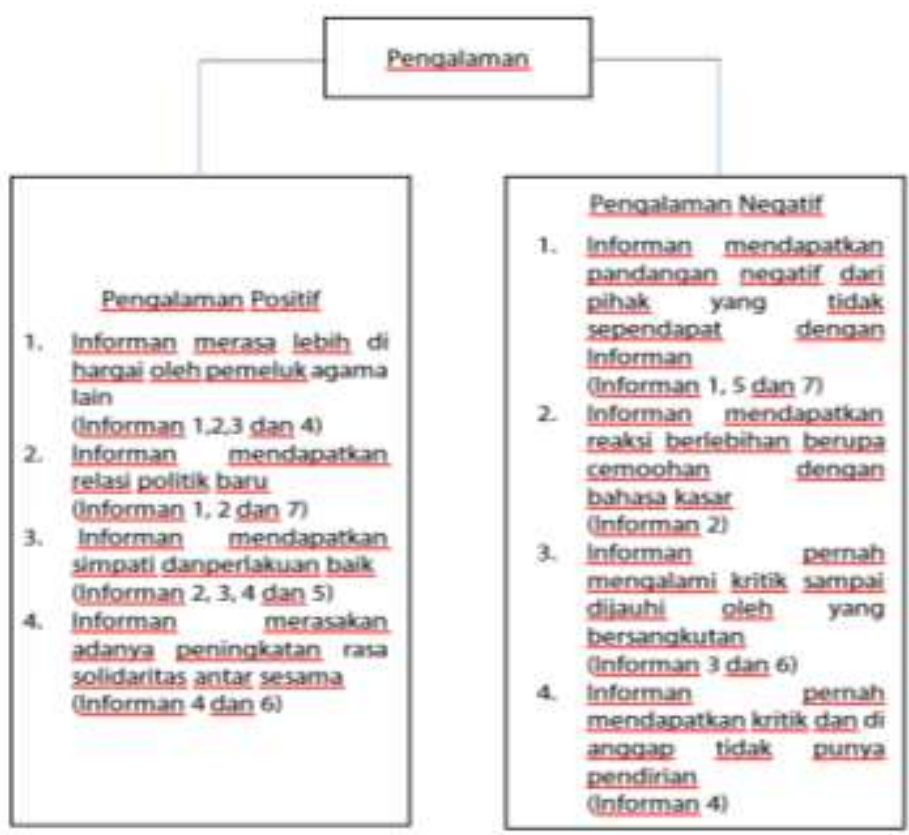

\section{Bagan 2}

Model Pengalaman Mengucapkan salam Om Swastiastu

(Sumber: Model kategorisasi hasil wawancara Informan)

\section{Makna Ucapan salam Om Swastiastu}

Berdasarkan hasil penelitian makna ucapan salam yang disampaikan 
oleh informan yaitu sebagai berikut:

\section{Mendoakan keselamatan}

Makna ucapan salam yakni mendoakan keselamtan disampaikan oleh KH. Asep MA (Informan 5) beliau memaparkan makna ucapan salam sebagai berikut :

Salam itu merupakan sunnatulloh artinya bagi seorang muslim mengucapkan salam sama halnya dengan ibadah karena akan mendapatkan pahala kebaikan, salam berasal dari kata assalamun artinya keselamatan makan makna ucapan salam adalah ucapan keselamatan dengan kata lain mendoakan keselamatan.

Makna ucapan salam yakni mendoakan keselamtan juga disampaikan oleh H. Majmudin (informan 1) beliau memaparkan makna ucapan salam sebagai berikut:

Salam merupakan kata yang diadopsi dari bahasa arab yang memiliki arti selamat, adapun makna salam yakni mendoakan keselamatan, dalam Islam ucapan salam yang kita kenal yaitu assalamualaikum yang artinya semoga keselamatan alloh terlimpah kepada kamu sekalian.

Sama halnya dengan H. Majmudin, Ayi Nurlubis (Informan 2), memaparkan makna ucapan salam yaitu mendoakan keselamatan. Berikut penjelasan terkait makna ucapan salam yang disampaikan oleh Ayi Nurlubis:

Ucapan salam itu pada dasarnya memiliki makna mendoakan keselamatan, bukan hanya salam yang berasal dari agama Islam saja yang memiliki makna mendoakan keselamatan saya rasa semua agama juga memaknai ucapan sebagai sebuah doa hanya pengambilan bahasanya saja yang berbeda.

\section{Adat kebiasaan}

Makna ucapan salam yakni suatu adat kebiasaan disampaikan oleh Briptu Yusuf (Informan 4) beliau memaparkan makna ucapan salam sebagai berikut:

Selain dari mendoakan keselamatan sebenarnya makna dari ucapan salam yaitu adat kebiasaan, dimana setiap pemeluk agama menurut saya sudah terbiasa saling menyapa dengan ucapan salam, oleh karena nya lebih tepat makna salam adalah adat kebiasaan. 
bahwa makna ucapan salam yakni adat kebiasaan. Berikut pemaparan dari Suherman :

Menurut saya ucapan salam maknanya adat kebiasaan, karena peradaban kita pada dasarnya dipengaruhi oleh budaya religi dalam hal ini ucapan salam termasuk aktivitas dalam bidang keagamaan yang telah menjadi budaya dimana sering diucapkan oleh orang-orang dalam aktivitas sehari-hari.

\section{Doa kebaikan versi Hindu}

Makna ucapan salam Om Swastiastu yakni doa keselamatan versi agama Hindu disampaikan oleh KH. Asep MA (Informan 5) beliau memaparkan makna ucapan salam Om Swastiastu sebagai berikut:

Ucapan salam Om swastiasu kurang lebih maknanya semoga kamu diberikan kebaikan. istilah Om ini merupakan kata yang sakral dalam agama hindu sama halnya dengan menyebut kata Alloh Swt dalam agama Islam dan salam Om Swastiastu dimaknai dengan doa yang dipanjatkan kepada tuhan dalam agama hindu untuk memohon perlindungan, keselamatan dan kebaikan.

Makna ucapan salam Om Swastiastu yakni doa kebaikan versi agama Hindu juga disampaikan oleh H. Majmudin (Informan 1) beliau memaparkan makna ucapan salam Om Swastiastu sebagai berikut:

Menurut saya pribadi ucapan salam Om Swastiastu itu merupakan salam dari agama Hindu maka makna ucapan salam Om Swastiastu kurang lebih mengharapkan kebaikan dalam versi agama Hindu.

Makna ucapan salam Om Swastiastu menurut saya itu adalah doa kebaikan,kebaikan disini termasuk mengharapkan kenikmatan, keselamtan dan lain sebagainya.

\section{Ungkapan bersyukur}

Makna ucapan salam Om Swastiastu yaitu ungkapan bersyukur disampaikan oleh Briptu Yusuf (Informan 4) beliau memaparkan makna ucapan salam Om Swastiastu sebagai berikut:

Menurut saya makna ucapan salam Om Swastiastu yaitu sebagai bentuk atau ungkapan bersyukur, bersyukur atas apa yang telah terjadi atau bersyukur atas apa yang telah didapatkan terutama bersyukur karena telah diberi keselamatan.

Sama halnya dengan yang disampaikan oleh Suherman

(Informan 6) yang memberikan pemaparan sebagai berikut : 
Ucapan salam om swastiastu ini kurang lebih maknanya adalah ungkapan bersyukur yang dilakukan oleh pemeluk agama hindu sebagai bentuk berterima kasih atas segala yang terlah diberikan oleh tuhan kepada manusia.

\section{Selamat di bumi, langit, dunia dan akhirat}

Makna ucapan salam Om Swastiastu yaitu salam di bumi, langit, dunia dan akhirat disampaikan oleh Ayi Nurlubis (Informan 2) beliau memaparkan makna ucapan salam Om Swastiastu sebagai berikut:

Menurut saya ucapan salam Om Swastiastu ini memiliki makna yang sangat hebat. Saya sampaikan terlebih dahulu bahwa pada dasarnya ucapan salam Om Swastiastu ini artinya mendoakan keselamatan hanya saja dalam bahasa agama hindu, adapun makna dari salam Om Swastiastu yaitu semoga selamat di bumi dan dilangit serta selamat di dunia dan di akhirat.

\section{Salam penyambutan (greeting)}

Makna ucapan salam Om Swastiastu yaitu salam penyambutan (greeting) disampaikan oleh Briptu Imam (Informan 3) beliau memaparkan makna ucapan salam Om Swastiastu sebagai berikut:

Berdasarkan pengalaman saya ketika berkunjung ke berbagai daerah terutama daerah yang mayoritas agama Hindu ucapan salam Om Swastiastu digunakan untuk menyambut atau menyapa tamuu atau pengunjung yang datang, menurut saya makna salam Om Swastiastu juga sebagai salam penyambutan.

Sama halnya dengan Bripda Yusuf (Informan 4) yang memaparkan penjelasan mengenai makna ucapan salam Om Swastiastu yaitu salam penyambutan. Berikut penjelasan makna ucapan salam Om Swastiastu yang di paparkan oleh Yusuf:

Selain dari mendoakan keselamatan, menurut saya makna dari ucapan salam om swastiastu yaitu salam peyambutan maksudnya ucapan salam yang digunakan ketika hendak menyambut tamu yang datang, di lingkungan militer sendiri saya memperhatikan bahwa ucapan salam om swastiastu diucapkan oleh prajurit militer beragama Hindu kepada sesama teman prajurit yang bertamu ke asramanya. 


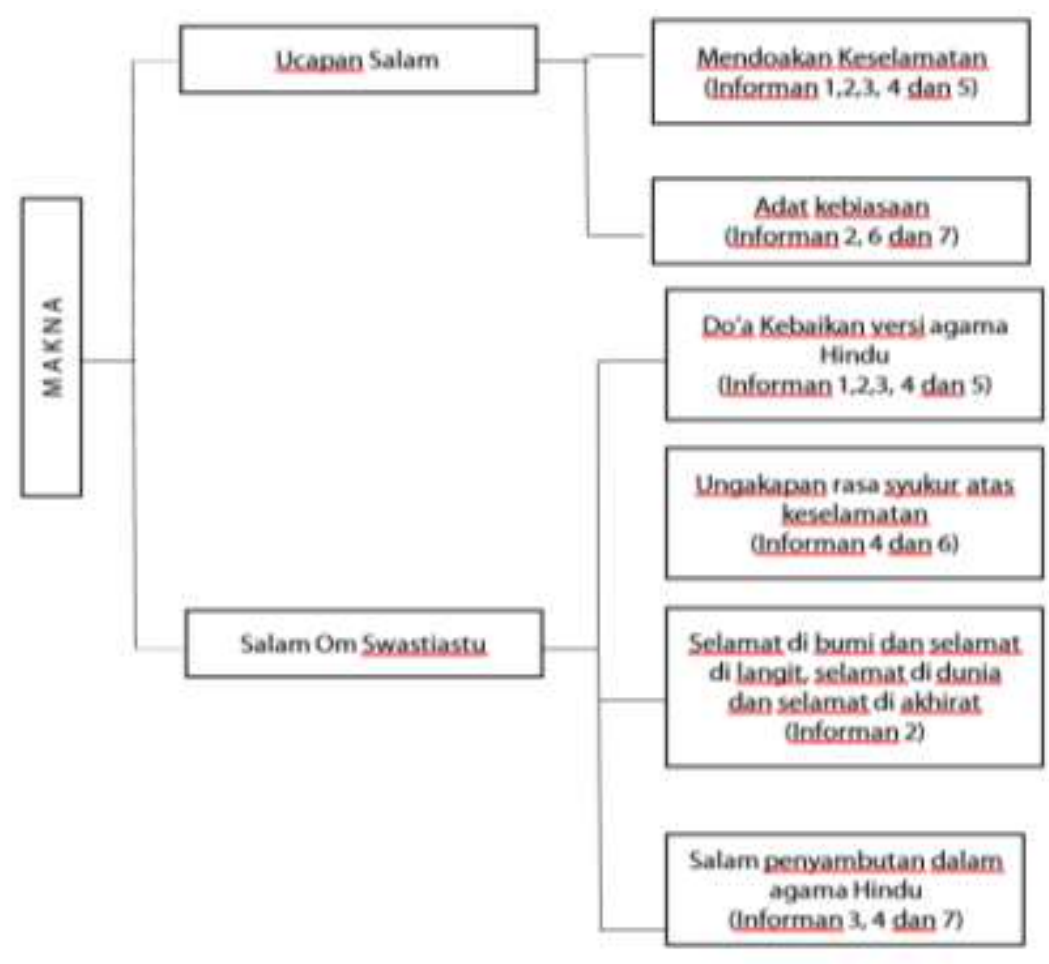

\section{Bagan 3}

Model Makna Mengucapkan salam Om Swastiastu

(Sumber: Model kategorisasi hasil wawancara Informan tahun 2018)

\section{Pembahasan}

Selain dari hasil wawancara dengan informan, penulis membutuhkan triangulasi untuk mendukung keabsahan data yang didapatkan di lapangan. Untuk itu penulis juga melakukan triangulasi sumber dengan dua orang narasumber yang memilki informasi yang relevan, memilki pengalaman yang juga sudah sangat dalam. Adapun wawancara narasumber pertama dilakukan dengan $\mathrm{KH}$. Ubaidillah, beliau merupakan agamawan dan pemimpin pondok pesantren modern dan dakwan Roudlotul Ulum Bandung serta menjabat sebagai anggota fatwa MUI Jawa Barat. Berdasarkan hasil wawancara dengan $\mathrm{KH}$. Ubaidillah mengenai makna ucapan salam Om Swastiastu, mengatakan bahwa fenomena ucapan salam Om Swastiastu yang diucapkan oleh pejabat biasanya 
pejabat bersangkutan memiliki tujuan lain selain dari unsur toleransi yakni untuk menunjukkan eksistensi diri dan pejabat yang mengucapkan salam Om Swastiastu tidak semuanya berasal dari kehendak pribadi akan tetapi ada juga karena adanya dorongan internal sehingga dewan atau pejabat tertentu diharuskan mengucapkan salam dalam berbagai versi agama termasuk ucapan salam Om Swastiastu (Wiadnyana, 2013).

Selain itu ucapan salam yang diucapkan oleh pejabat ini kemungkinan akan berdampak baik bagi yang bersangkutan yaitu menambah relasi politik dan mempererat hubungan dengan dewan lainnya meskipun terdapat dampak negatifnya seperti munculnya pandangan negatif respon tidak berupa kritik oleh yang bersangkutan. Kemudian beliau menjelaskan bahwa makna dari ucapan salam Om Swastiastu yaitu mendoakan kebaikan dalam versi agama Hindu. Selain KH. Ubaidillah selaku agamawan, peneliti juga melakukan wawancara triangulasi dengan Prof. Dr. Hj. Ummu Salamah M.S, beliau adalah Dekan Fakultas Ilmu Komunikasi Universitas Garut juga sebagai ahli bidang Sosiologi. Berdasarkan hasil wawancara dengan Ummu Salamah mengenai makna ucapan salam Om swastiastu, beliau menjelaskan bahwa dalam perspektif sosiologi fenomena ucapan salam Om Swastiasu merupakan suatu wujud toleransi antar umat berbeda agama juga suatu bentuk semangat kebangsaan dan nasionalisme. Beliau juga menjelaskan bahwa latar belakang fenomena ucapan salam ini dipengaruhi oleh dua motif berbeda, pertama yaitu dorongan yang berasal dari internal partai dan yang kedua yaitu dorongan yang timbul dari hati nurani yang mengatakan bahwa ucapan salam dalam berbagai versi agama ini meruapakan bentuk implementasi dari bhineka tunggal ika (Gerungan, 2010).

Sementara itu makna ucapan salam Om swastiastu merupakan salah satu etika yang baik dan telah menjadi budaya kita, makna ucapan sendiri selain dari doa salam juga telah menjadi adat kebiasaan untuk saling menghormati satu sama lain (Husaeni, 2010). Selain itu ucapan salam Om Swastiastu juga merupakan salam penyambutan yang biasa digunakan untuk memberikan penyambutan (greeting) kepada seseorang. Peneliti juga melakukan wawancara triangulasi dengan tokoh yang berasal dari agama Hindu yaitu Peltu I Wayan Pratama. Berdasarkan hasil wawancara dengan I Wayan terkait fenomena ucapan salam dalam berbagai versi agama termasuk ucapan salam Om swastiastu pada 
perspektif beliau hal tersebut salah satu bentuk atau cara dalam bertoleransi, beliau menegaskan bahwa hal tersebut sifatnya baik dan positif sebagai implementasi dari berdemokrasi. I Wayan juga menjelaskan bahwa tentunya akan terdapat pro kontra pada fenomena ini dan menghasilkan pengalaman baik dan buruk. Kemudian berkaitan dengan makna dari ucapan salam Om Swastiastu makna secara utuh nya yaitu mendoakan agar kita selalu diberikan atau berada dalam kebaikan, salam dari semua agama tentunya memiliki makna yang berbeda akan tetapi tujuannya tetap sama yakni mengharapkan kebaikan atau keselamatan dan lain sebagainya.

\section{Simpulan}

Berdasarkan hasil penelitian dan pembahasan, maka penelitian ini dapat disimpulkan bahwa:

1. Motif salam om swastiastu yang diucapkan oleh informan sebagai orang yang mengucapksan salam dalam berbagai versi agama sebagai eksistensi diri, tujuan lainnya untuk menunjukan sikap toleransi antar umat beragama. Informan yang mengucapkan salam dalam berbagai versi agama termasuk ucapan salam om swastiastu dilatar belakangi oleh beberapa faktor yaitu dorongan internal, semangat kebangsaan rasa nasionalisme dan prinsip netralitas.

2. Pengalaman positif yang dialami oleh informan diantaranya merasa di hargai oleh pemeluk agama Hindu, mendapatkan relasi politik baru, mendapatkan perlakuan baik, mandapatkan simpati dari berbagai pihak serta timbulnya rasa solidaritas antar sesama pemeluk agama. Sedangkan pengalaman negatif yang dialami informan setelah mengucapkan salam dalam berbagai versi agama termasuk ucapan salam om swastiastu diantaranya mandapatkan perluakuan kurang baik dari beberapa pihak yang tidak sependapat dengan ucapan salam tersebut sampai mendapatkan cemoohan berupa perkataan kasar, mendapatkan kritik dan di jauhi oleh beberapa pihak serta dianggap tidak memiliki pendirian oleh orang-orang di lingkungannya.

3. Makna ucapan salam om swastiastu bukan hanya sekedar mengucapkan ucapan salam lebih dari itu ucapan salam om swastiastu ini 
mendoakankeselamatan, selain itu makna salam om swastiastu memiliki makna keselamatan di dunia dan diakhirat serta salam om swastiastu juga dimaknai sebagai salam penyambutan. Bagi semua informan mengucapkan salam sudah menjadi kebiasaan dan memiliki arti mendoakan keselamatan untuk keselamatan di dunia dan di akhirat.

\section{Referensi}

Aisyah, Siti. 2013. Pola Komunikasi Antar Umat Beragama (Studi Komunikasi Antarbudaya Tionghoa dengan Muslim Pribumi di Rw 04 Kelurahan Mekarsari Tangerang. Jakarta: Universitas Islam Syarif Hidayatulloh.

Aga, Bali. 2006. Ragam Istilah Hindu. Denpasar: Tim Bali Aga.

Bungin, Burhan. 2010. Metodologi Penelitian Kualitatif. Jakarta: Rajawali Pers. Gerungan. 2010. Psikologi Sosial. Bandung: PT.Refika Aditama.

Hermawan, Awan. 2010. "Komunikasi Antar Umat Berbeda Agama". Jurnal Komunikasi Dan Realitas Sosial.Volume 1 No 1.

Husaini, Adian. 2006. Pluralisme Agama: Parasit bagi Agama-agama. Jakarta: Dewan Da'wah Islamiyah Indonesia.

Komarudin, Acep. 2015. Pemahaman Hadist Larangan Mengucapkan dan Menjawab Salam Terhadap Non Muslim. Jakarta: Universitas Islam Syarif Hidayatulloh.

Kuswarno, Engkus. 2013. Fenomenologi Konsepsi, Pedoman dan Contoh Penelitian. Bandung: Widya Padjajaran.

Salam, Abdus. 2017. Sebarkan Salam, Kiat Mudah Menjaga Kasih Sayang dan Ukhuwah. Depok: Pustaka Khazanah Fawa'id.

Wiadnyana, Agus. 2013. Istilah Hindu, Perbendaharaan Kata dalam Kitab Smrti Veda dan Nama-nama Dewata Hindu. Gianyar: Gandapura.

Yahya, Ahmad Syarif. 2017. Ngaji Toleransi. J akarta: Gramedia. 